\title{
REGENERASI KEARIFAN LOKAL KESENIAN LEBON SEBAGAI BUDAYA LELUHUR PANGANDARAN, JAWA BARAT
}

\author{
Agus Nero Sofyan, Kunto Sofianto, Maman Sutirman, dan Dadang Suganda \\ Fakultas Ilmu Budaya, Universitas Padjadjaran \\ E-mail: agus.nero@unpad.ac.id
}

\begin{abstract}
ABSTRAK. Penelitian ini berjudul "Regenerasi Kearifan Lokal Kesenian Lebon sebagai Budaya Leluhur Pangandaran, Jawa Barat". Bertujuan memperoleh data dan informasi kearifan lokal lebon sebagai budaya leluhur Kabupaten Pangandaran. Metode penelitian menggunakan kualitatif-deskriptif dengan pendekatan kajian etnografi, yaitu metode yang digunakan sebagai untuk mendeskripsikan kebudayaan dan aspek-aspeknya. Teknik pengumpulan data adalah survei ke lapangan melalui wawancara, pengamatan secara langsung, dan pengambilan sumber-sumber tertulis dari masyarakat dan pemerintah setempat. Masalah yang dibahas adalah bagaimana nilai historis yang ada pada kesenian tradisional lebon Pangandaran dan bagimana proses regenerasi kesenian lebon dari generasi tua kepada generasi muda. Hasil yang dicapai dari penelitian ini adalah kesenian lebon Pangandaran memiliki sejarah panjang dalam perkembangannya di wilayah Pangandaran; upaya pelestarian kesenian lebon di antaranya: (a) adanya pembinaan sedini mungkin (usia SD) memperkenalkan seni leluhur ini kepada generasi penerus, (b) adanya peran pemerintah berupa peningkatan fasilitas (adanya pelatihan dan workshop).
\end{abstract}

Kata kunci: regenerasi; kearifan lokal; kesenian lebon; Pangandaran; Jawa Barat

\section{THE REGENERATION OF LOCAL WISDOM OF LEBON ART AS AN ANCESTRAL CULTURE OF PANGANDARAN, JAWA BARAT}

\begin{abstract}
This study entitled "the Regeneration of Local Wisdom of Lebon Art as Ancestral Culture of Pangandaran Regency, West Java". This study aims to obtain data and information about Lebon local wisdom as the ancestral culture of Pangandaran Regency. The method in this study is qualitative-descriptive with ethnography approach, which is a method used to describe culture and its aspects. Data collection techniques in this study is a survey of the field through interviews, direct observations, and taking written sources from the community and local government. The problem discussed in this study is how the historical values that exist in the Lebon Pangandaran traditional art and how the process of regeneration of the Lebon arts from the older generation to the younger generation. The results achieved from this research are the Lebon Pangandaran art has a long history in its development in the Pangandaran region; efforts to preserve the Lebon arts include: (a) there is guidance as early as possible (elementary school age) introducing this ancestral art to the next generation, (b) the role of government in the form of improving facilities (training and workshops).
\end{abstract}

Key words: regeneration; local wisdom; Lebon art; Pangandaran; West Java

\section{PENDAHULUAN}

Kompleksitas kultural yang ada di Indonesia menjadi cerminan kemajemukan kehidupan masyarakat pendukungnya. Kemajemukan yang ada diperlihatkan dengan adanya keanekaragaman budaya, lingkungan, alam, dan wilayah geografis. Dalam hubungannya dengan keanekaragaman budaya, masyarakat Indonesia telah memperlihatkan adanya keragaman seni tradisional yang tersebar di berbagai daerah. Keanekaragaman kesenian tradisional ini menjadi satu di antara kekayaan intelektual yang erat kaitannya dengan kekayaan sosiokultural yang mesti dijaga, dilestarikan, dan dikembangkan. Sebagai satu aspek di antara tujuh unsur kebudayaan, kesenian tradisional telah lahir, tumbuh, dan berkembang di tengah-tengah kehidupan masyarakat pendukungnya, baik secara alami maupun nonalami. Artinya, kesenian merupakan milik bersama dari suatu kelompok sosial dan menjadi cerminan sistem nilainya (Kasman, 2011).
Kesenian tradisional, ditinjau dari konteks kajian budaya yang lebih luas, telah menjadi satu di antara unsurkebudayaan yang dapat dijadikan sebagai subkajian utamanya. Kajian mengenai kesenian tradisional, dengan seperangkat nilai estetiknya, bukanlah suatu hal yang monolitis. Keberadannya sangat berhubungan erat dengan unsur-unsur pokok lainnya, seperti aspek religi, ekonomi, struktur sosial, politik, dan sebagainya. Nilai estetika yang ada di dalam kesenian tradisional merupakan gejala implisit yang berkorelasi dengan konstruksi yang lebih besar, yaitu sosiokultural dalam makna yang lebih umum. Hal ini dapat dipahami bahwa nilai estetika seni adalah fenomena sensoris yang mengandung makna implisit (Kasman, 2011; Suharto, 2012).

Proses regenerasi kesenian melalui pendidikan indeginius menjadi sesuatu yang amat penting dalam proses penjagaan dan pelestarian kekayaan intelektual berbasis kearifan lokal di wilayah manapun (Isnan \& Rohmiyati, 2016; Musthofa, 2018). Kondisi ini akan menjadi dilematis apabia dalam proses 
regenerasinya, minim sumbangsih dari pihak-pihak terkait, seperti praktisi kesenian berbasis kearifan lokal, para pegiat kesenian, pemerintah daerah, dan sebagainya. Minimnya kesadaran kultural dari para praktisi, misalnya, tentu akan berdampak pada kurangnya proses regenerasi dari generasi tua kepada generasi muda. Oleh sebab itu, posisi kesadaran sosiokultural dan kepekaan nalar untuk menjaga dan melestarikan kearifan lokal menjadi suatu hal yang sangat penting keberadannya. Apabila hal tersebut diabaikan, proses pelestarian keterampilan berbasis kearifan lokal akan terhambat. Hal ini dapat dipahami bahwa pada saat ini pemertahanan kehidupan budaya dan tradisi masyarakat Sunda sedikit demi sedikit mulai termarginalkan (Gunardi, 2014). Dalam kondisi demikian, peran peneliti budaya pun tidak kalah pentingnya dalam proses pelestarian dan pendokumentasian budaya lokal yang ada di suatu wilayah tertentu. Hal ini seperti yang disampaikan Wikandia bahwa penelitin secara tidak langsung telah membantu pelestarian budaya lokal (Wikandia, 2016).

Kearifan lokal, apapun jenis dan bentuknya, merupakan sekumpulan pengetahuan yang telah diselenggarakan secara dinamis, berkembang, dan dilanjutkan oleh populasi tertentu yang terintegrasi dengan persepsi mereka terhadap alam dan budaya di sekitanya. Dalam hubungannya dengan praktik kultural, kearifan lokal juga memiliki fungsi yang sangat vital, yakni sebagai dasar untuk pengambilan serangkaian kebijakan pada tingkat lokal dalam berbagai bidang kehidupan, seperti kesehatan, pendidikan, pertanian, pengelolaan sumber daya alam, dan kegiatan masyarakat pedesaan. Kearifan lokal menjadi piranti pemahaman yang sudah sedemikian menyatu dengan norma kehidupan, sistem kepercayaan, dan budaya yang pada masanya nanti diekspresikan melalui serangkaian tradisi dan mitos yang menjadi sistem keyakinan dalam jangka waktu yang lama.

Kearifan lokal yang bekenaan dengan sistem ekonomi tradisional yang ada di masyarakat, dewasa ini menjadi topik pemabahasan yang menarik untuk diangkat di tengah semakin menipisnya sumber daya alam dan kompleksnya permasalahan dalam upaya pemberdayaan potensi masyarakat. Setidaknya ada dua alasan utama yang menempatkan kearifan lokal menjadi elemen penentu keberhasilan pembangunan sumber daya masyarakat dan sumber daya alam sekitar. Pertama, adanya kekhawatiran terhadap peningkatan intensitas kerusakan sumber daya akibat ulah tangan manusia. Kedua, meningkatnya persaingan ekonomi menuju ekonomia global yang memengaruhi sendi-sendi kehidupan masyarakat, sehingga disadari ataupun tidak telah menggeser kearifan lokal menjadi kearifan ekonomi. Kedua faktor ini jika dipahami secara seksama, seharusnya membuat masyarakat semakin destruktif dalam mengembangkan potensi kearifan lokal yang ada di tengah-tengah masyarakat, terutama dalam hal ikhwal pengelolaan produksi, distribusi, dan pemasaran produk hasil dari praktik kerajinan berbasis kearifan lokal tersebut.

Jawa Barat merupakan wilayah yang diidentikan dengan budaya Sunda. Ketika berbicara mengenai budaya Jawa Barat, identitas yang muncul adalah Sunda. Hal ini disebabkan oleh masyarakat Sunda menempati sebagian besar wilayah Jawa Barat, yaitu Bekasi, Depok, Bogor, Sukabumi, Cianjur, Karawang, Subang, Purwakarta, Cimahi, Bandung, Garut, Sumedang, Indramayu, Majalengka, Cirebon, Kuningan, Ciamis, Tasikmalaya, Pangandaran, dan Banjar. Sebagai bagian dari wilayah Indonesia, Jawa Barat, khususnya Priangan Timur telah memberikan sumbangsih kultural berupa kebudayaan lokal dan tradisional yang lahir dan berkembang di daerahdaerah tersebut. Satu di antara wilayah Priangan Timur yang memiliki sumbangan besar dalam mengembangkan kebudayaan tradisional Jawa Barat adalah Pangandaran.

Masyarakat Sunda di Pangandaran tentu memiliki seni yang khas dan berkarakter. Seni tersebut meliputi seni rupa (gambar, patung, tekstil, dan keramik), seni pertunjukan (musik, tari, dan teater), seni sastra (prosa dan puisi, lisan dan tertulis), dan seni media rekam (Emilda, Rohaeni, \& Listiani, 2016; Marpaung, 2013; Ratih \& Sondarika, 2017; Suhaeti, 2019)which consists of several islands. So called archipelago that has outstanding cultural richness and are not owned by another country, one of the Indonesian national pride by having a diversity of ethnic, tribal customs that have high values inherited by our ancestors to be conserved and have value quite high as a tool to build character as a nation and is the capital of local wisdom very proud of each region through provincial and district/ city in the archipelago along still recognized and not contrary to the values of national wisdom that the values of pancasila . Indigenous people (MAHUdAT . Selain itu, ada juga seni kriya (kerajinan tangan) dan seni bela diri. Kesenian yang dijadikan objek kajian pada kesempatan kali ini adalah kesenian lebon yang merupakan satu di antara kesenian ikonik Kabupaten Pangandaran.

Kabupaten Pangandaran merupakan daerah otonomi baru yang berdiri pada tanggal 25 Oktober 2012. Secara sosiohistoris, Pangandaran terlahir sebagai satu wilayah yang memiliki kompleksitas 
kultural; memiliki penampuran kultur yang beragam, satu di antaranya adalah pencampuran budaya Sunda dan budaya Jawa. Kondisi sosiokultural yang ada di Pangandaran tidak bisa dilepaskan dari pengaruh geografis Pangandaran yang menjadi daerah perbatasan antara Provinsi Jawa Barat dan Provinsi Jawa Tengah (Cilacap). Kondisi ini menjadikan Pangandaran sebagai satu di antara dearah yang ada di Jawa Barat yang memiliki kekayaan budaya yang cukup beragam. Kompleksitas kultural tersebut terlihat juga dalam kesenia tradisionalnya, seperti kesenian lebon. Kesenian lebon, secara etimologis, diambil dari sisipan bahasa Jawa dan bahasa Sunda, yaitu lebboni (bahasa Jawa) yang artinya diboehan 'dikafani' dan lebokna (bahasa Sunda) yang artinya dilebok atau dikurebeun kana taneuh 'dikubur'.

Kesenian lebon memiliki sejarah panjang dalam perkembangannya di wilayah Pangandaran. Kesenian ini lahir dan berkembang sejak masa Kerajaan Galuh (Sunda) yang kemudian kerajaan tersebut runtuh dan diambil alih oleh Kerajaan Mataram (Jawa) pada tahun 1650. Secara historis, perkembangan seni lebon tidak dapat dilepaskan dari latar belakanng sejarah yang berbeda pada setiap masa. Latar belakang historis tersebut menyebabkan adanya perbedaan konsep dan substansi yang ditampilkan pada kesenian lebon. Meskipun demikian, hal yang paling substansial dari kesenian lebon adalah ada pada kondisi faktual di tengah perkembangan globalisasi dewasa ini. Keberadaan kesenian lebon sedikit demi sedikit telah mengalami penurunan animo, termasuk dari masyarakat pendukungnya.

Kesenian lebon, meskipun memiliki sejarah panjang di tengah masyarakat Pangandaran, dewasa ini kurang mendapatkan apresiasi dari masyarakatnya. Jika kondisi ini terus dibiarkan, akan mengarah pada proses kepunahan kesenian lebon di tengah masyarakat Pangandaran. Padahal, Kabupaten Pangandaran sekarang ini sedang disiapkan menjadi satu di antara kawasan wisata yang ada di Provinsi Jawa Barat. Tentu jika kita cermati, salah satu aspek yang memiliki potensi untuk dikembangkan adalah wisata budaya, termasuk kesenian lebon di dalamnya. Itulah sebabnya, upaya serius dari berbagai pihak untuk terus menjaga, melestarikan, dan mengembangkan kekayaan intelektual berupa kesenian tradisional, termasuk kesenian lebon, di Kabupaten Pangandaran menjadi satu hal yang perlu dilakukan.

Penelitian ini bertujuan untuk mengungkap seluk-beluk kesenian tradisional lebon dalam konstelasi historis sebagai kekayaan intelektual berbasis kearifan lokal yang ada dan berkembang di
Kabupaten Pangandaran sehingga menjadi budaya leluhur Pangandaran yang ikonik, proses regenerasi melalui pendidikan indeginius yang berkembang menjadi pengetahuan terlembagakan sebagai model kesenian tradisional lebon yang unik dan khas, serta memberikan sumbangsih intelektual kepada pihakpihak terkait untuk mampu menjaga dan melestarikan kekayaan intelektual berbasis kearifan lokal tersebut.

\section{METODE}

Pendekatan yang digunakan dalam penelitian ini terdiri atas dua, yaitu pendekatan teoretis dan pendekatan metodologis. Secara teoretis, pendekatan yang digunakan di dalam penelitian ini adalah pendekatan etnografi. Etnografi merupakan satu di antara istilah yang merujuk pada penelitian kualitatif (Idrus, 2009). Adapun secara metodologis, penelitian ini menggunakan metode kualitatif-deskriptif. Secara kualitatif artinya data yang diteliti dan hasil analisisnya diperoleh dari rekaman, pengamatan, wawancara, atau bahan tertulis dan data ini tidak berbentuk angka (Djojosuroto \& Sumaryati, 2004).

Etnografi diartikan sebagai usaha mendeskripsikan kebudayaan dan aspek-aspeknya dengan mempertimbangkan latar belakang permasalahan secara menyeluruh. Etnografi sebagai bentuk penelitian memiliki beberapa karakteristik, yaitu sebagai berikut:

a. selalu menekankan pada penggalian alamiah fenomena sosial yang khusus;

b. memiliki data yang terstruktur dan rancangan penelitiannya bersifat terbuka;

c. dalam melakukan penelitiannya, peneliti bertindak sebagai instrumen yang berupaya menggali data yang dibutuhkan terkait dengan fokus penelitian;

d. kasus yang diteliti cenderung sedikit atau bahkan hanya satu kasus yang kemudian dikaji secara mendalam;

e. analisis data tentang makna dan fungsi perilaku manusia ditafsirkan secara eksplisit dalam bentuk deskripsi dan penjelasan verbal;

f. etnografi tidak menggunakan analisis statistik, tetapi tidak berarti menolak data yang berupa angka-angka.

Dengan menggunakan kajian etnografi, dapat diungkapkan fakta kebudayaan masyarakat di Kabupaten Pangandaran. Kebudayaan yang dimaksud dalam penelitian ini adalah kesenian tradisional lebon secara mendalam dan komprehensif. Metode etnografi yang digunakan dalam penelitian ini merujuk pada metode etnografi sebagai analisis maju bertahap (Gumilang, 2016). Analisis data 
dilakukan sejak tahap pengumpulan data dan secara bertahap terus dilakukan hingga akhir peneltian. Akhir penelitian ditentukan sepenuhnya oleh peneliti. Hal ini disebabkan oleh penelitian etnografi dapat mengungkapkan hasil penelitian kebudayaan yang sempurna dan komprehensif.

Data penelitian diambil dari informan pokok dan informan pangkal. Data yang diperoleh berupa data reflektif dan data tafsiran yang berbentuk narasi. Teknik pengumpulan data dilakukan dengan observasi dan wawancara mendalam (deep interview). Hasil penelitian berupa sekumpulan informasi dan temuan yang disusun berdasarkan fokus penelitian, dikelompokkan, dihubungkan antara informasi yang satu dengan informasi lainnya, kemudian diberi pemaknaan.

Lokasi penelitian yaitu Kabupaten Pangandaran, khususnya di sentra-sentra kesenian tradisional lebon. Data dijaring menggunakan metode observasi, yaitu dengan melakukan pengamatan sercara langsung ke objek peneliian untuk melihat dan mengamati dari dekat kegiatan dan praktik kultural yang dilakukan (Murti, 2018). Selain itu, data juga dijaring dengan cara melakukan pencatatan secara teliti dan langsung datang ke lokasi penelitian yang berkenaan dengan praktik kesenian tradisional lebon di Kabupaten Pangandaran. Observasi juga dilakukan dengan mendatangi lokasi yang menjadi tempat kegiatan pementasan dan mencari sumber lainnya, yaitu untuk mengetahui latar belakang keberadaan kesenian tradisional lebon di Kabupaten Pangandaran, eksisting kesenian tersebut, proses pementasan pertarungan antarjawara, dan hal ikhwal lainnya seputar kesenian tradisional lebon di Kabupaten Pangandaran.

Untuk mendapatkan data yang komprehensif, dilakukan juga wawancara terstruktur kepada informan yang ada di wilayah penelitian. Wawancara merupakan percakapan dengan maksud tertentu yang dilakukan untuk mendapatkan informasi dan keterangan yang berhubungan dengan objek penelitian, dilakukandenganmengajukan serangkaian pertanyaan dan informan memberikan jawaban atas pertanyaan-pertanyaan tersebut (Moleong, 2007). Dalam konteks penelitian ini, wawancara dilakukan dengan tujuan untuk mendapatkan informasi dan keterangan yang jelas, akurat, dan komprehensif tentang kesenian tradisional lebon di Kabupaten Pangandaran. Informan yang dimintai keterangan adalah salah seorang praktisi dan pegiat kesenian tradisional lebon yang ada di wilayah tersebut, yaitu Pak Apan.

Penjaringan data juga dilakukan dengan pendokumentasian. Dokumentasi itu sendiri dipahami sebagai sumber yang memberikan informasi, fakta, dan keterangan kepada peneliti, baik berupa catatan, foto, video, rekaman, dan sebagainya (Murti, 2018). Itu artinya bahwa dokumentasi dapat berupa catatan peristiwa yang lampau dan sudah berlalu yang berupa gambar, tulisan, atau karya seseorang (Sugiono, 2011). Dalam konteks penelitian ini, dokumentasi dijadikan sebagai sumber data sekunder yang digunakan untuk memperkuat data-data primer yang sudah dijaring di lapangan, melalui wawancara dan observasi yang dilakukan oleh peneliti. Dokumentasi yang dimaksud dalam penelitian ini bisa berupa buku, katalog, majalah, facebook, internet yang berisi tentang informasi dan keterangan yang bekenaan dengan objek penelitian, yaitu kesenian tradisional lebon Pangandaran.

Untuk mendapatkan data yang akurat dan komprehensif, dilakukan triangulasi data. Dalam konteks penelitian ini, triangulasi dapat dipahami sebagai teknik pengumpulan data yang bersifat penggabungan dari berbagai teknik pengumpulan sumber data dan sumber data yang telah ada (Sugiono, 2011). Teknik triangulasi dalam penelitian ini dilakukan dengan cara membandingkan data kepada sumber data yang sama dengan teknik yang berlainan, yaitu data yang diperoleh dengan wawancara, kemudian dicek dan dibandingkan dengan hasil wawancara dan observasi.

Dalam konteks penelitian ini, triangulasi data yang dilakukan oleh penulis adalah dengan menggunakan hasil wawacara dan sumber tertulis. Di dalam triangulasi ini, penulis menggunakan beberapa sumber pengumpulan data, yaitu melalui wawancara kepada Pak Apan sebagai salah satu tokoh masyarakat dan sekaligus pegiat kesenian tradisional lebon di Kabupaten Pangandaran; fotofoto dan dokumentasi yang berkaitan dengan kesenian tradisional lebon di Pangandaran.

\section{HASIL DAN PEMBAHASAN}

\section{Kabupaten Pangandaran Selayang Pandang}

Undang-undang nomor 21 tahun 2012 mendasari lahirnya kabupaten baru (DOB) yang ditandatangani oleh Presiden Susilo Bambang Yudhoyono pada tanggal 16 November tahun 2012. Kemudian diundangkan oleh Menteri Hukum dan HAM Amir Syamsudin pada tanggal 17 November tahun 2012, maka Pangandaran resmi menjadi Kabupaten di Provinsi Jawa Barat. Dalam UU No. 21/2012 disebutkan, Kabupaten Pangandaran berasal dari sebagian wilayah Kabupaten Ciamis, yang terdiri dari: Kecamatan Parigi, Kecamatan Cijulang, Kecamatan Cimerak, Kecamatan Cigugur, 
Kecamatan Langkaplancar, Kecamatan Mangunjaya, Kecamatan Padaherang, Kecamatan Kalipucang, Kecamatan Pangandaran dan Kecamatan Sidamulih. Ibu Kota Kabupaten Pangandaran berkedudukan di Kecamatan Parigi.

Sebagai kabupaten baru, fokus publik biasanya ialah pada tingkat pendapatan asli daerahnya. Kabupaten Pangandaran memiliki PAD sekitar Rp.53,6 milyar pada tahun 2015, jauh lebih rendah bila dibandingkan dengan kabupaten/kota lain di Jawa Barat atau hanya 10\% dari daerah lainnya. Demikian pula dengan pajak daerah, rasionya hanya $7 \%$ dari rata-rata pajak daerah kabupaten/kota di Jawa Barat.

Dengan potensi yang besar dibidang pariwisata maka misi Kabupaten Pangandaran yaitu "Kabupaten Pangandaran Pada tahun 2025 menjadi kabupaten pariwisata yang mendunia, tempat tinggal yang aman dan nyaman berlandaskan norma agama.

Secara umum dapat dikatakan bahwa wisata utama Pangandaran adalah pantai yang berjumlah banyak dan dominan serta berfungsi sebagai penarik utama (anchor). Kemudian jenis obyek wisata berkembang menjadi wisata lembah/sungai, curug (air terjun), goa dan lain sebagainya.

Selain potensi parawisata ternyata Kabupaten Pangandaran juga memiliki potensi pertanian yang cukup memadai. Luas sawah di Kabupaten Ciamis berdasarkan data Dinas Pertanian Tanaman Pangan Kabupaten Ciamis pada Tahun 2012 tercatat 51.903 Ha dan 26 persen ada di Kabupaten Pangandaran atau sekitar 13 ribu Ha dengan sawah irigasi dan tadah hujan.

Pertanian tanaman padi (sawah dan ladang) merupakan komoditas utama di sektor pertanian. Data produksi tanaman padi (sawah dan ladang) tahun 2012 Kabupaten Ciamis tercatat 688.891 ton dan 31 persen disumbang dari produksi Kabupaten Pangandaran atau mencapai 214.044 ton. Sub sektor pertanian palawija Kabupaten Pangandaran juga tidak kalah potensial untuk ditingkatkan dengan jumlah produksi pada tahun yang sama dengan komoditas unggulan jagung 6.152 ton, ubi kayu 11.300 ton, ubi jalar 2.520 ton, kacang tanah 752 ton, kacang kedelai 2.084 ton, kacang hijau 725 ton dan komoditas lainnya. Belum lagi potensi komoditas hortikultura yang bisa dikembangkan.

\section{Kesenian Tradisional Lebon dalam Tinjauan Historis}

Kesenian lebon memiliki sejarah panjang dalam perkembangannya di wilayah Pangandaran. Kesenian ini lahir dan berkembang sejak masa Kerajaan Galuh (Sunda) yang kemudian kerajaan tersebut runtuh dan diambil alih oleh Kerajaan Mataram (Jawa) pada tahun 1650. Secara historis, perkembangan seni lebon tidak dapat dilepaskan dari latar belakang sejarah yang berbeda pada setiap masa. Latar belakang historis tersebut menyebabkan adanya perbedaan konsep dan substansi yang ditampilkan pada kesenian lebon. Kerajaan Mataram pada waktu itu menguasai wilayah Kerajaan Galuh di bagian kidul dan mempunyai tangan kanan yang bernama Sukapura. Kerajaan Mataram memiliki visi politik yang cukup besar untuk menguasai wilayah Kerajaan Galuh yang lain dan disertai dengan adanya dendam politik yang cukup besar untuk misi balas dendam. Konstelasi politik yang ada pada Kerajaan Mataram waktu itu akhirnya memaksa pihak kerajaan untuk melakukan sayembara terbuka berupa pemilihan jagoan tarung (Nurwahyuni, 2017). Kerajaan Mataram mengumpulkan seluruh masyarakat dan memaksa mereka yang memenuhi kriteria untuk mengikuti tarung antarjagoan di setiap daerah. Pertarungan ini harus menghasilkan jawara lembur yang pada masanya nanti akan dijadikan sebagai pasukan pengaman antardaerah. Selain itu, jawara lembur juga akan dijadikan sebagai pasukan inti untuk misi balas dendam Kerajaan Mataram. Peserta yang dipanggil untuk mengikuti pertaruan antarjawara pada kesenian lebon adalah para jawara yang memenuhi kriteria yang diseleksi di seluruh wilayah Pangandaran - pada waktu itu menjadi bagian wilayah Kerajaan Galuh Kidul. Pertarungan antarjawara yang dilaksanakan oleh Kerajaan Mataram ini akhirnya berlangsung terus menerus, hingga menjadi satu tradisi turun temurun dan kemudian menjadi satu kesenian yang berkembang di wilayah terebut. Kesenian terebut kemudian dinamakan kesenian lebon.

Kesenian lebon, secara etimologis, diambil dari sisipan bahasa Jawa dan bahasa Sunda, yaitu lebboni (bahasa Jawa) yang artinya diboehan 'dikafani' dan lebokna (bahasa Sunda) yang artinya dilebok atau dikurebeun kana taneuh 'dikubur' (Nurwahyuni, 2017). Dalam pertunjukan kesenian lebon pada awal masa kelahirannya, pihak yang kalah akan langsung dikubur di tempat pertarungan. Oleh sebab itu, dua belah pihak jawara yang bertarung, masing-masing telah menyiapkan kain kafan, pacul, dan sekop untuk menguburkan lawan yang kalan dalam pertarungan.

Sebagai sebuah kesenian, lebon baru mulai dikenal oleh masyarakat Pangandaran pada tahun 1950 (Nurwahyuni, 2017). Kesenian ini dijadikan sebagai satu di antara tradisi adat pertarungan jawara antarkampung dan satu di antara kebudayaan untuk menyelesaikan suatu permasalahan yang ada di tengah-tengah masyarakat, seperti sengketa 
lahan dan sengketa wilayah yang sudah tidak dapat diselesaikan pada zaman dahulu dan akhirnya diselesaikan dengan seni lebon.

Ditinjau dari substansi pertunjukannya, seni lebon ditengarai lahir dan berkembang sebelum masuknya Islam ke Pangandaran. Bentuk kesenian ini didukung oleh kepercayaan masyarakat setempat, yaitu Hindu. Masyarakat Pangandaran, pada awal mula lahirnya lebon, mempercayai bahwa pertumpahan darah merupakan satu hal yang biasa, bahkan diharapkan akan memunculkan keseimbangan kosmos (Apan, wawancara pada 23 Juli 2019).

Dalam konteks politik yang berkembang pada awal mula lahirnya lebon, yaitu kondisi politik yang berupa kerajaan-kerajaan kecil, kesenian lebon dijadikan sebagai satu di antara upaya penggalangan kekuatan politik kerajaan untuk mempertahankan dan memperluas wilayah kekuasaannya. Oleh sebab latar historis tersebut, kesenian lebon menjadi satu dia antara kesenian yang identik dengan kekerasan berupa pertumpahan darah dan pertarungan.

Dalam perkembangannya, kesenian lebon sempat hilang seiring dengan adanya gerakan DI TII yang masuk ke wilayah tersebut (Apan, wawancara pada 23 Juli 2019). Namun, pada akhirnya kesenian lebon kembali dimunculkan dengan konsep yang berbeda pada tahun 1950. Sejak saat itu, kesenian lebon berubah menjadi bentuk pementasan seni reka dari adegan pertarungan lebon yang sesungguhnya dengan dibuat alur cerita yang menarik agar tetap terlihat seperti aslinya. Untuk menghindari cedera dalam pertarungan antarjawara, digunakan pelindung di beberapa bagian tubuhnya. Bagian tubuh yang dilindungi itu adalah kepala dengan menggunakan pelepah daun pinang yang dibungkus dengan kain, tangan sampai siku, dan kaki, terutama bagian betis dengan menggunakan kulit hewan. Untuk mengalahkan lawannya, tiap-tiap petarung diberi sebuah alat pukul yang terbuat dari rotan.

\section{Pertunjukan Kesenian Lebon}

Kesenian lebon ditampilkan dengan menggunakan kostum dan alur cerita yang khas. Kostum yang digunakan dalam kesenian lebon di antaranya adalah: selimut bergaris yang digunakan untuk penutup kepala pemain; tiga buah sarung yang digunakan untuk paha kanan dan kiri, serta untuk ekor (ekor digunakan untuk memancing emosi lawan dan pada saat pertarungan usai, pemenang akan mengibaskan ekornya untuk memancing emosi agar lawan bangkit dan bertarung kembali); totopong (penutup kepala) yang terbuat dari kulit sapi; ubeg yang berfungsi sebagai tameng atau pelindung dan memiliki bentuk menyerupai sarung tangan serta terbuat dari kulit sapi yang diikat oleh rotan; dan batang pemukul yang terbuat dari rotan (hoé) dan dibungkus oleh sarung lalu diikat dengan menggunakan tali waru (Apan, wawancara pada 23 Juli 2019).

Alur pertunjukan seni lebon juga memiliki karakteristik yang khas yang menjadi pembeda dengan seni pertunjukan lainnya. Secara keseluruhan, alur pertunjukan seni lebon diawali dengan bubuka (pembukaan), inti, dan penutup.

Pertunjukan seni lebon diawali dengan iringan musik, yaitu musik bubuka (musik pembuka). Iringan musik tersebut disebut musik tatalu dengan diiringi serangkaian waditra dan terompet Sunda. Musik bubuka ini juga dilengkapi dengan iringan lagu yang dinamakan kidung pangrajah. Sambil diiringi musik bubuka, kemudian muncul seorang pasepuh yang membawa parukuyan (sebuah wadah kecil tempat membakar kemenyan). Pasepuh tersebut kemudian mulai membakar kemenyan serta menyiapkan makanan sesajian berupa ketupat, tangtang angin, bubur bereum, bubur bodas, kopi pahit, kopi manis, panggang ayam, dan kelapa hijau. Proses penyajian makanan ini diyakini oleh masyarakat setempat sebagai sebuah upaya agar pertunjukkan lebon dapat berjalan dengan lancar; tanpa mengalami adanya gangguan yang akan terjadi.

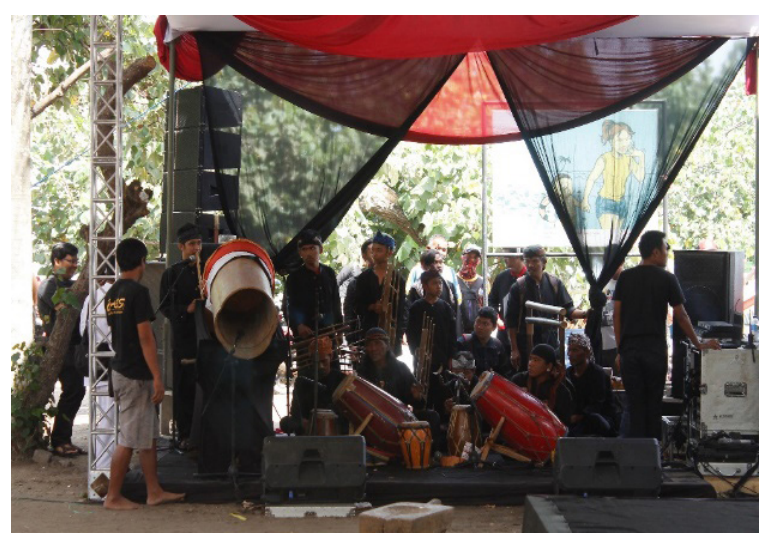

Gambar 1. Iringan Musik pada Pertunjukan Lebon Sumber: dokumentasi peneliti

Pertunjukan kemudian dilanjutkan dengan acara inti, pertarungan antarjawara yang telah disiapkan oleh kelompok yang mendaftar. Pertarungan dimulai ketika malandang (pengatur pertarungan) memasuki arena dan memberikan serangkaian aturan dan kesepakatan yang berlaku selama pertandingan. Adapun kesepakatan yang harus dipenuhi oleh para pemain, diantaranya, tidak boleh ada rasa dendam setelah selesainya pertandingan; tidak ada kecurangan pada setiap jawara selama pertandingan berlangsung; dan harus sportif. Adapun aturan yang diberlakukan selama pertarungan berlangsung 
dalam kesenian lebon adalah batas serangan, setiap jawara boleh melakukan serangan ke setiap arah kecuali bagian alat vital dan wajah lawan. Selain itu, malandang mengecek para jawara untuk menghindari kecurangan antara keduanya, seperti benda tajam atau semburan yang disembunyikan dalam mulut jawara untuk melemahkan penglihatan lawan.

Selanjutnya, bobotoh (pendukung) akan memanggil jawaranya. Lalu para jawara diminta berdiri melingkar di luar arena pertarungan untuk diberi jampe-jampe oleh tiap-tiap sesepuh kelompok. Tidak sembarang orang dapat ditunjuk menjadi sesepuh dalam kesenian lebon, karena sesepuh merupakan orang yang memiliki kelebihan dalam bidang ilmu rohaniah dan dianggap memiliki kesaktian yang diakui kapasitasnya oleh masyarakat pada kelompok tersebut. Fungsi sesepuh diantaranya untuk mentransfer ilmu tenaga dalam kepada jawara dan mengobati jawara. Jampe-jampe yang diberikan oleh tiap-tiap sesepuh kepada jawaranya memiliki makna tersendiri dan dianggap rahasia sebagai kekuatan yang dimiliki pada setiap kelompok. Sesepuh memiliki kiat-kiat tersendiri untuk mendalami ilmunya, diantaranya puasa dan bersemedi. Ketika wasit meniupkan peluit dan tempo iringan kendang semakin cepat yang menandakan bahwa pertandingan akan segera dimulai, malandang memanggil para jawara agar segera menempatkan posisi di tengah area pertandingan. Selanjutnya, malandang akan meminta para jawara untuk saling berkenalan. Perkenalan yang dilakukan hanya sebatas salaman dan memeluk satu sama lain sebagai makna tidak adanya dendam apabila permainan telah selesai.

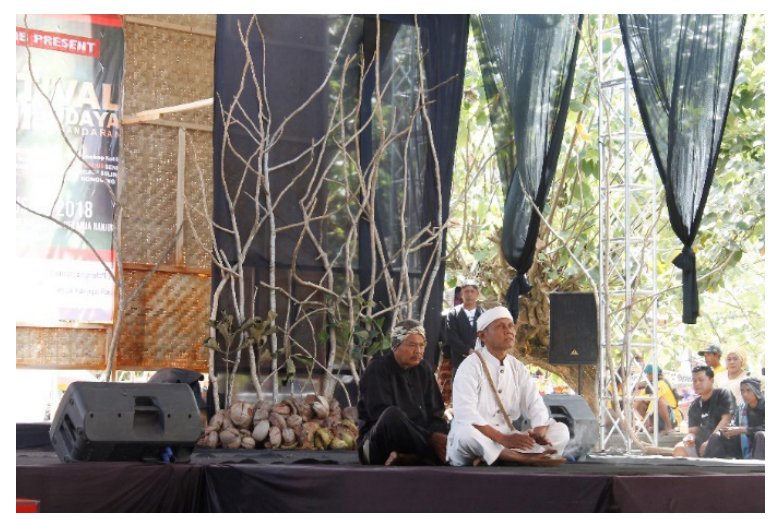

Gambar 2. Proses Pembacaan Jampe-Jampe oleh Sesepuh Sumber: dokumentasi peneliti

Setelah pertarungan selesai, panitia akan mengumumkan pemenang dari pertarungan lebon dengan cara mecungkeun hoe (mengangkat bambu). Jawara yang ditetapkan sebagai pemenang, akan mengibasibaskan ekornya dan jawara yang kalah akan dibawa ke luar arena pertarungan oleh bobotoh-nya.

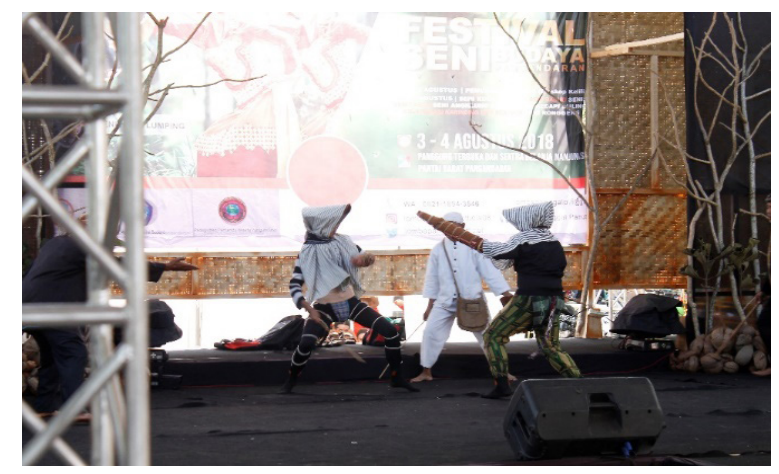

Gambar 3 Pertarungan Antarjawara

Sumber: dokumentasi peneliti

Pertunjukan kesenian lebon menampilkan dua kubu petarung yang memiliki jawara yang didampingi olehparabobotoh (pendukung). Kesenian lebon biasanya dilakukan di arena terbuka dengan formasi para bobotoh melingkar mengelilingi jawara yang bertarung di tengah arena pertandingan dan dipimpin oleh satu wasit untuk mengatur jalannya pertandingan. Jumlah pekerja seni yang dibutuhkan dalam pementasan lebon berjumlah kurang lebih 15; empat orang pemain utama, empat orang atau lebih sebagai bobotoh, satu orang sebagai wasit, satu orang sesepuh, satu orang sebagai pemain kendang pencak, satu orang pemain indung, satu orang pemain kendang anak, satu orang pemain blanter, dan satu orang sebagai pemegang kempul dan kecrek. Pemain utama pada kesenian lebon bervariasi, mulai dari kalangan anak anak, remaja, hingga dewasa. Adu ketangkasan atau pertarungan pada kesenian lebon biasanya berlangsung selama tiga babak, setiap babak berdurasi sekitar 20 s.d. 25 menit.

Para seniman lebon, untuk menjaga eksistensi dan keberangsungan kesenian tersebut, melakukan beberapa inovasi agar kesenian tersebut tetap dapat dinikmati dan dilestarikan di zaman sekarang. Beberapa inovasi dalam segi pertunjukkan, antara lain adanya pembacaan sinopsis, narasi pembuka, narasi penantang, narasi penerima tantangan, dan narasi penutup. Selain itu, para bobotoh membawa angklung dan kohkol (kentongan) sebagai identitas antarlawan dan peramai suasana.

\section{Upaya Pelestarian Kesenian Lebon Pangandaran}

Sebagai satu di antara kesenian tradisional ikonik Kabupaten Pangandaran, lebon harus terus dijaga dan dilestarikan. Keberadannya sebagai aset intelektual yang berhubungan dengan pengetahuan tradisional, kesenian ini sedikit-banyaknya telah memberikan sumbangsih kultural dalam meningkatkan daya tarik wisata budaya di Kabupaten Pangandaran. Akan tetapi, fakta di lapangan terungkap bahwa regenerasi pegiat lebon mengalami kendala. Hal ini tampak bahwa generasi penerus tidak/kurang tertarik untuk 
mengikuti jejak orang tuanya sebagai pegiat kesenian lebon.

Atas dasar hal itu, tim peneliti memberikan rekomendasi untuk kelestarian kesenian lebon, yaitu sebagai berikut: (a) adanya pembinaan sedini mungkin (usia SD) memperkenalkan seni leluhur ini kepada generasi penerus, (b) adanya peran pemerintah berupa peningkatan fasilitas (adanya pelatihan dan workshop).

Dalam konteks pembinaan sedini mungkin, mesti ada upaya serius dari berbagi pihak, khususnya para praktisi yang berkecimpung di dunia kesenian tradisional lebon untuk berlapang hati mengajarkan kompetensi kesenian ini kepada generasi-generasi muda di lingkungan Pangandaran. Hal ini menjadi vital adanya, karena pemertahanan seni dan pelestarian seni mesti dilakukan dengan adanya pewarisan kompetensi dari generasi tua kepada generasi muda. Selain itu, bukan hanya mengajarkannya, tetapi mesti ada upaya motivasi yang bersifat kultural kepada generasi muda agar mau mempelajari kompetensi kultural tersebut.

Selain itu, mesti ada upaya serius pula dari pihak pemerintahan daerah untuk melestarikan dan menjaga aset intelektual ini. Sebagai pihak yang memiliki wewenang untuk mengambil kebijakan tertentu, pemerintah daerah diharapkan memberikan perhatian lebih untuk melestarikan aset intelektual ini. Ada beberapa hal yang bisa dilakukan oleh pemerintah daerah untuk menjaga dan melestarikan kesenian tradisional lebon ini, di antaranya adalah dengan memberikan bantuan dana untuk para pegiat dan praktisi yang berkecimpung di dunia kesenian tradisional lebon Pangandaran. Selain itu, pemerintah daerah juga bisa membantu memperkenalkan kesenian lebon Pangandaran ke khalayak umum, bahkan bisa dijadikan sebagai satu di antara objek pertunjukan bertajuk pariwisata budaya.

Dalam konteks kebijakan, kesenian tradisional lebon pangandaran mesti dilestarikan dengan menuangkannya ke dalam bentuk tertulis, contohnya buku-buku referensi pembelajaran di sekolahsekolah. Sebuah buku pembelajaran, khususnya buku pembelajaran bahasa Indonesia tentang sastra, berbasis kearifan lokal kesenian lebon Pangandaran dapat dibuat dan diajarkan kepada anak-anak didik. Bentuknya bisa berupa buku sastra didaktis, karena memuat nilai-nilai kedidaktisan. Solusi penulis untuk masalah ini adalah mesti adanya pengembangan buku cerita anak berbasis kearifan lokal lebon Pangandaran untuk sekolah dasar. Buku cerita anak berbasis kearifan lokal lebon Pangandaran mesti dikembangkan dengan adanya penyesuaian karakteristik bahan bacaan cerita anak tersebut.

\section{SIMPULAN}

Berdasarkan hasil pemaparan tersebut, dapat disimpulkan bahwa kesenian lebon memiliki sejarah panjang dalam perkembangannya di wilayah Pangandaran. Kesenian ini lahir dan berkembang sejak masa Kerajaan Galuh (Sunda) yang kemudian kerajaan tersebut runtuh dan diambil alih oleh Kerajaan Mataram (Jawa) pada tahun 1650. Secara historis, perkembangan seni lebon tidak dapat dilepaskan dari latar belakang sejarah yang berbeda pada setiap masa. Latar belakang historis tersebut menyebabkan adanya perbedaan konsep dan substansi yang ditampilkan pada kesenian lebon.

Sebagai sebuah kesenian, lebon baru mulai dikenal oleh masyarakat Pangandaran pada tahun 1950. Kesenian ini dijadikan sebagai satu di antara tradisi adat pertarungan jawara antarkampung dan satu di antara kebudayaan untuk menyelesaikan suatu permasalahan yang ada di tengah-tengah masyarakat, seperti sengketa lahan dan sengketa wilayah yang sudah tidak dapat diselesaikan pada zaman dahulu dan akhirnya diselesaikan dengan seni lebon.

Kesenian lebon ditampilkan dengan menggunakan kostum dan alur cerita yang khas. Kostum yang digunakan dalam kesenian lebon di antaranya adalah: selimut bergaris, tiga buah sarung, totopong (penutup kepala), ubeg, dan batang pemukul.

Alur pertunjukan seni lebon juga memiliki karakteristik yang khas yang menjadi pembeda dengan seni pertunjukan lainnya. Secara keseluruhan, alur pertunjukan seni lebon diawali dengan bubuka (pembukaan), inti, dan penutup.

Upaya pelestarian kesenian lebon di antaranya: (a) adanya pembinaan sedini mungkin (usia SD) memperkenalkan seni leluhur ini kepada generasi penerus, (b) adanya peran pemerintah berupa peningkatan fasilitas (adanya pelatihan dan workshop).

\section{DAFTAR PUSTAKA}

Djojosuroto, K. \& Sumaryati, M. L. . (2004). PrinsipPrinsip Dasar dalam Penelitian Bahasa dan Sastra. Bandung: Nuansa.

Emilda, N., Rohaeni, A.J. \& Listiani, W. (2016). Seni Tradisi Gondang Buhun sebagai Pendidikan Karakter dan Ekowisata: Upaya Meningkatkan Kesejahteraan Masyarakat Kabupaten Pangandaran Jawa Barat. Seminar Nasional Hasil Penelitian Dan Pengabdian Kepada Masyarakat, 614-621.

Gumilang, G.S. (2016). Metode Penelitian Kualitatif dalam Bidang Bimbingan dan Konseling. Jurnal Fokus Konseling, 2, (2), 144-159. 
Gunardi, G. (2014). Peran Budaya "Mikanyaah Munding" Dalam Konservasi Seni Tradisi Sunda. Panggung, 24, (4), 329-334. https:// doi.org/10.26742/panggung.v24i4.129

Idrus, M. (2009). Metode Penelitian Ilmu Sosial. Yogyakarta: Erlangga.

Isnan, H., \& Rohmiyati, Y. (2016). Pelestarian Pengetahuan Seni Ukir Masyarakat Minangkabau. Jurnal Ilmu Perpustakaan, 5, (1), 1-12.

Kasman, S. (2011). Komodifikasi Kesenian Tradisional Wacana Estetika Posmodern dalam Pariwisata. Ekspresi Seni Jurnal Ilmu Pengetahuan Dan Karya Seni, 13, (2), 163-174. https://doi.org/10.1017/ CBO9781107415324.004

Marpaung, L. A. (2013). Urgensi Kearifan Lokal Membentuk Karakter Bangsa Dalam Rangka Pelaksanaan Otonomi Daerah. Yustisia, 2, (2), 120-131. https://doi.org/10.20961/yustisia. v2i2.10204

Moleong, L. J. (2007). Metodologi Penelitian Kualitatif. Bandung: Remaja Rosdakarya.

Murti, K. A. H. (2018). Kerajinan Anyam Bambu di Sanggar Hamid Jaya Desa Gintangan Kecamatan Rogojampi Kabupaten Banyuwangi. Jurnal Seni Rupa, 06, (01).

Musthofa, B. M. (2018). Pengembangan Budaya Menuju Kesejahteraan Budaya: Pelajaran Dari Pengembangan Masyarakat Di Saung Angklung Udjo, Bandung, Jawa Barat.
Sosio Informa, 4, (3), 553-566. https://doi. org/10.33007/inf.v4i3.1600

Nurwahyuni, A. (2017). Kesenian Lebon di Desa Selasari Kabupaten Pangandaran. Universitas Pendidikan Indonesia.

Ratih, D., \& Sondarika, W. (2017). Analisis Potensi Desa Ditinjau dari Sosial Budaya Kesenian Tradisional Ronggeng Gunung dalam Meningkatkan Pendapatan Masyarakat Prasejahtera (Studi Kasus di Desa Ciulu Kecamatan Banjarsari Kabupaten Ciamis Jawa Barat). Jurnal Artefak: History and Education, 4, (2), 161-166.

Sugiono. (2011). Metode Penelitian Kuantitatif Kualitatif dan $R \& D$. Bandung: Alfabeta.

Suhaeti, E. (2019). Perubahan Ronggeng Amen di Kecamatan Padaherang Kabupaten Pangandaran. Panggung, 29, (1), 29-42. https://doi.org/10.26742/panggung.v29i1.812

Suharto. (2012). Problematika Pelaksanaan Pendidikan Seni Musik Di Sekolah Kejuruan NonSeni.Harmonia-Journalof Arts Research and Education, 12, (1), 87-94. https://doi. org/10.15294/harmonia.v12i1.2221

Wikandia, R. (2016). Pelestarian dan Pengembangan Seni Ajeng Sinar Pusaka pada Penyambutan Pengantin Khas Karawang. Panggung, 26, (1), 58-69. https://doi.org/10.26742/ panggung.v26i1.162

Wawancara: Apan (69 tahun), tokoh masyarakat. Tanggal 23 Juli 2019. 